\author{
Marzenna Cyzman \\ Instytut Literatury Polskiej, Wydział Filologiczny \\ Uniwersytet Mikołaja Kopernika w Torunia \\ e-mail: marzennacyzman@poczta.onet.pl \\ ORCID: 0000-0002-5530-2351
}

\title{
Myślę, więc czuję, dotykam, smakuję... O myśleniu Pana Cogito. Kilka refleksji epistemologicznych
}

Przystępując do interpretacji wierszy Zbigniewa Herberta, którego twórczość obrosła w przebogatą i ogromną literaturę krytyczną, badacz czuje się bezradny ${ }^{1}$. Wie, że nie sprosta wymogom naukowej rzetelności. Chcąc bowiem sformułować spójną, dodajmy - kolejną interpretację, musi znacznie ograniczyć odwołania do tego, co już w zakresie badań nad utworami tego znanego poety zrobiono. Ogromna liczba istniejących prac nie tylko wywołuje uczucie bezsilności, ale też badawczą przekorę. W polskim dyskursie literaturoznawczym interpretacje twórczości Herberta wydają się od lat ustabilizowane. $W$ ich ramach rozwijają się takie stałe wątki, jak Herbertowskie pojęcie sztuki, wartości etyczne wyrażane $\mathrm{w}$ jego utworach, zaangażowanie polityczne i relacja względem rzeczywistości, ujęcie świata i człowieka na niej egzystującego. Ten ostatni wydaje mi się najbardziej interesujący. Jest on cały czas niedostatecznie rozwinięty i dopracowany, co dziwi, zważywszy na obecność wątków ontologicznych i epistemologicznych nie tylko w wierszach Herberta, ale i w jego esejach czy listach. W licznych interpretacjach poświęconych temu zagadnieniu pojawia się wprawdzie stały korpus słów i wyrażeń wskazujących na kontekst epistemologiczny rozważań, jak np. „docieranie do źródła”, "poszukiwanie istoty”, "docieranie do prawdy”,

\footnotetext{
1 Dlatego dla zachowania spójności rozważań rezygnuję tu ze wskazania prac na temat twórczości Herberta, a te, do których będę się wprost odwoływać, podane zostaną w przypisach.
} 
„niemożność adekwatnego opisu przedmiotu”, „wierność rzeczywistości”, "metafizyka" itd. ${ }^{2}$, jednak bez należytej ich problematyzacji. Niech za przykład takich rozlicznych ujęć stosunku Herberta do świata posłuży krótki cytat z książki Magdaleny Śniedziewskiej pod znamiennym tytułem Wierność rzeczywistości: „Istotne dla Herberta jest przecież to, by podkreślić wyższość rzeczywistości nad jej słownym przedstawieniem" ${ }^{3}$. Zdanie to w sposób najbardziej chyba znamienny presuponuje paradygmat epistemologiczny, w który wprowadza się poezję Herberta w rodzimym dyskursie literaturoznawczym. Jest to paradygmat realistyczny (oczywiście nie w sensie naiwnego realizmu) i esencjalistyczny. Przekonanie, że autor pragnie dotrzeć do istoty rzeczy, nawet jeśli jego utwory poświadczają wahanie czy niemożność osiągnięcia tego celu, dowodzi przecież, że w esencję się jednak wierzy. Silne ustabilizowanie interpretacji wierszy Herberta w kontekście paradygmatu realistycznego stawia opór nowym, innym interpretacjom, ale jednocześnie prowokuje przekornego badacza do próby ich sformułowania. I to nie w celu wywołania badawczego fermentu czy literaturoznawczej awantury, lecz raczej z przeświadczenia, iż ów realistyczny paradygmat jest jednak $w$ odniesieniu do złożonej materii epistemologicznej utworów Herberta niewystarczający. Czy dlatego, że badacze dotychczas się mylili lub gubili pewne istotne wątki Herbertowskiego myślenia? Sądzę, że nie w potencjalnych błędach tkwi problem i nie o weryfikację dotychczasowych ustaleń powinno tu chodzić, lecz raczej o zaproponowanie dla nich takiego układu odniesienia, w świetle którego zyskałyby one nową wykładnię. Skoro nie paradygmat realistyczny, to konstruktywistyczny - ten wniosek jest jedynie pozornie tak oczywisty ${ }^{4}$. Przeciwieństwo dla paradygmatu realistycznego stanowi wprawdzie paradygmat konstruktywistyczny, taką też dychotomią operuje się w filozofii, jednak wobec nowszych, postkonstruktywistycznych tendencji w humanistyce ${ }^{5}$ różnice między obu modelami poznania przestały być problematyzowane $\mathrm{w}$ takim

2 Taki korpus leksykalny odnajdziemy choćby w interpretacjach pomieszczonych w zbiorze Między nami a światem. Bóg i świat w twórczości Zbigniewa Herberta, red. G. Halkiewicz-Sojak, J.M. Ruszar, R. Sioma, Torun - Kraków 2012.

3 M. Śniedziewska, Wierność rzeczywistości. Zbigniew Herbert o postawie wobec świata i problemach jego reprezentacji, Kraków 2013, s. 84. Praca ta jest reprezentatywna względem realistycznej tendencji epistemologicznej w interpretacjach twórczości Herberta.

4 Pierwszą bodaj próbę interpretacji twórczości Zbigniewa Herberta w kontekście konstruktywizmu podjął Radosław Sioma w znanym mi, choć dotychczas nieopublikowanym artykule Czy Zbigniew Herbert byt konstruktywista? Notatki do znacznie większej całości. Kontekst konstruktywistyczny nie jest tu jeszcze uściślony, wydaje się zbyt szeroki dla przeprowadzenia spójnych rozumowań, ale artykuł zawiera wiele cennych sugestii poznawczych.

5 Przykład ilustrujący tę tendencję odnajdziemy np. w artykule Ewy Bińczyk (Post)konstruktywizm na temat technonauki, "Zagadnienia Naukoznawstwa” 2010, nr 2, s. 231-251. 
stopniu, jak jeszcze kilkanaście lat temu. Z perspektywy czasu wydają się zresztą wyolbrzymione, bowiem wtedy, gdy spór jeszcze trwał, wynikały $\mathrm{w}$ dużej mierze $\mathrm{z}$ chęci (skądinąd zrozumiałej) obronienia przez realistów status quo, a przez konstruktywistów z chęci (również zrozumiałej) wprowadzenia nowego, i ich zdaniem lepszego, ujęcia relacji podmiot-przedmiot ${ }^{6}$. Ogromne znaczenie ma tu także fakt, iż konstruktywizm nie jest kierunkiem spójnym i jednolitym, zasadniej jest zatem mówić o konstruktywizmach, a wprowadzając jakiś problem w kontekst konstruktywistyczny, powinno się wyraźnie zaznaczyć, o jakim konstruktywizmie mówimy, by uniknąć nieścisłości. Takie uściślenia, zwłaszcza w polskim dyskursie literaturoznawczym, wydają się szczególnie pożądane, ba - nieodzowne, konstruktywizm na rodzimym gruncie jest mało znany. Jako kolejny -izm importowany zza granicy, przede wszystkim z Niemiec i Stanów Zjednoczonych, funkcjonujący $\mathrm{w}$ nielicznych przekładach, obrósł $\mathrm{w}$ wiele zupełnie chybionych interpretacji i konotacji, które nierzadko wykluczają go z domeny racjonalnego namysłu. Konstruktywizm posądza się o relatywizm, interpretacyjną dowolność, negację rzeczywistości, a nawet o nieetyczność. Dlatego też, by uniknąć nieporozumień, należy bardzo ściśle określić, jaki rodzaj konstruktywizmu bierzemy pod uwagę jako potencjalny kontekst interpretacyjny dla wierszy Herberta.

Konstruktywizm należy odnosić nie do kierunku metodologicznego, tym bowiem nigdy w żadnej ze swych odmian nie był, lecz raczej do określonej tendencji epistemologicznej w humanistyce ${ }^{7}$. Najbardziej ścisłe wydaje

6 Nie mogę tu rozwinąć tego wątku, jest on bowiem zbyt obszerny, wskażę zatem na, moim zdaniem, najbardziej trafne i lapidarne omówienie relacji realizmu i konstruktywizmu: J. Mitterer, (Radical) Constructivism - What Difference Does It Make?, "Constructivist Foundations" 2008, Vol. 3, No. 3, s. 160-162. Mitterer różnic między obu kierunkami upatruje raczej w ich dyskursywnych sformułowaniach, w technikach argumentacji i środkach retorycznych, jakie są wykorzystywane $\mathrm{w}$ tekstach przez ich przedstawicieli, zwłaszcza w sytuacji sporu. Kwestia ta tłumaczy się $\mathrm{w}$ ramach nie-dualizującego sposobu mówienia, retorycznego projektu samego Mitterera, por. M. Cyzman, Nieznośna płynność rzeczy. Dyskurs, retoryka, interpretacja w nie-dualizującym sposobie mówienia, Torun 2015.

7 Więcej na temat konstruktywizmu i jego różnych wymiarów oraz odmian, por. E. Kuźma, Konstruktywizm, w: Konstruktywizm w badaniach literackich, red. E. Kuźma, J. Madejski, A. Skrendo, Kraków 2006, s. 1-12; M. Wendland, Wiele twarzy konstruktywizmu. Różnorodność stanowisk konstruktywistycznych i ich klasyfikacje, „Kultura i Historia”, www.kulturaihistoria.umcs.lublin. pl/archives/5004 [dostęp 01.09.2017]; E. Piotrowska, Społeczny konstruktywizm a matematyka, Poznań 2008; S. Schmidt, Rzeczywistość obserwatora, w: Radykalny konstruktywizm. Antologia, red. B. Balicki, D. Lewiński, B. Ryż, E. Szczerbuk, Wrocław 2010, s. 243-260. Najbardziej chyba syntetyczne ujęcie konstruktywizmu zaproponowali ostatnio Marzenna Cyzman i Paweł Bohuszewicz w artykule Wokót pojęcia konstruktywizmu, „Litteraria Copernicana” 2016, nr 3, s. 7-14. Zob. także M. Cyzman, Nieznośna płynność rzeczy. Dyskurs, retoryka, interpretacja w nie-dualizujacym sposobie mówienia, s. 308-362. 
się pojęcie radykalnego konstruktywizmu i ten właśnie nurt będę mieć dalej na uwadze. Jego definicję sformułował w latach 80. XX w. Ernst von Glasersfeld, niemiecki myśliciel o wszechstronnych zainteresowaniach badawczych (filozofia, psychologia, cybernetyka, neurologia) we wstępie do książki pod redakcją Paula Watzlawicka Die erfundende Wirklichkeit ${ }^{8}$. U podstaw konstruktywizmu leży założenie o konstrukcyjnym, nie-reprezentacjonistycznym charakterze poznania/wiedzy. Poznanie, określane $\mathrm{w}$ wielu pracach mianem kognicji, jest rozumiane jako proces twórczy, dynamiczny, aktywny, oparty na doświadczeniu. Przedmiot poznania jest konstruowany lub współkonstruowany w kontekście kultury, społeczeństwa, wspólnot interpretacyjnych ${ }^{9}$. Polega ono na takim gromadzeniu doświadczeń, na takim podejmowaniu i przewidywaniu kolejnych aktywności, by podmiot poznający, jako system żywy, przeżył i w sposób skuteczny, wiabilny ${ }^{10}$ zagospodarował się w świecie. Rzeczywistość stanowi efekt konstrukcji podmiotu poznającego, konstrukcji dokonującej się zawsze w kontekście społecznym ${ }^{11}$.

Na podstawie tez radykalnie konstruktywistycznych, przede wszystkim Glasersfelda i chilijskiego biologa Humberta Maturany, polski badacz Adam Skibiński sformułował ciekawy projekt systemowo-konstruktywistycznej nauki o języku i poznaniu, który chciałabym uczynić głównym kontekstem dla rozważań o twórczości Herberta. Konstruktywiści przywiązywali szcze-

\footnotetext{
8 W wersji angielskiej: E. von Glasersfeld, An introduction to radical constructivism, w: The Invented Reality: How Do We Know What We Believe We Know? (Contributions to Constructivism), red. P. Watzlawick, W.W. Norton and Co, Norton, New York, s. 17-40; http://www.vonglasers feld.com/070.1. Upraszczam tu znacznie genezę radykalnego konstruktywizmu, pomijam też kwestię odmian $\mathrm{w}$ łonie samego radykalnego konstruktywizmu, jak np. biokonstruktywizm H. Maturany i F. Vareli, por. więcej na ten temat: K. H. Müller, Non-dualistic? Radical Constructivist?, „Constructivist Foundations" 2008, Vol. 3, No. 3, s. 181-191.

9 Jest to pojęcie wprowadzone do humanistyki przez amerykańskiego badacza literatury Stanleya Fisha. Nigdy nie zostało ono przez niego jednak ściśle zdefiniowane. Wspólnota interpretacyjna odnosi się prymarnie do zbioru podzielanych przez pewną grupę ludzi przekonań, przesądów i przed-rozumień. Pojęciem tym Fish posługuje się bardzo często w swoich tekstach, przede wszystkim tych, które są zawartych w zbiorze Interpretacja, retoryka, polityka, red. A. Szahaj, Kraków 2008.

10 Wiabilność to pojęcie pochodzące z teorii ewolucjonistycznych. Wiabilny oznacza „zdolny do przeżycia w określonym środowisku".

11 Pełną definicję radykalnego konstruktywizmu można znaleźć w artykule Bogdana Balickiego [B. Balicki, Nauka (o literaturze) z punktu widzenia radykalnego konstruktywizmu, w: Wzorce postrzegania rzeczywistości w nauce i społeczeństwie, red. B. Płonka-Syroka, Warszawa 2008, s. 210-211]. Definicja ta oparta jest w znacznym stopniu na biologicznych tezach H. Maturany (systemy żywe są autopojetyczne, czyli samosprawcze i samoreferencyjne, posługują się autoobserwacją $\mathrm{w}$ celu reprodukowania pewnych wzorców funkcjonowania, dzięki temu są wiabilne, a zatem zdolne do przeżycia w określonym środowisku), jako taka dla prowadzonych tu przeze mnie rozważań wydaje się mniej funkcjonalna.
} 
gólną wagę do języka, co bynajmniej nie prowadziło do uznania jego prymatu względem rzeczywistości czy językowego jej charakteru, ale raczej do przeformułowania sposobu, w jaki tradycyjnie ujmowano język. Dla Maturany linguistic behaviour is orienting bahaviour, co w kontekście jego tez z pogranicza biologii, neurologii i filozofii oznacza, że zachowanie językowe ma charakter orientujący. Tezę tę podziela również prawodawca radykalnego konstruktywizmu Glasersfeld ${ }^{12}$. Obaj myśliciele używają tu neologizmu languaging, którego polskim odpowiednikiem mogłoby być słowo ,językowanie", brzmiące jednak dość niefortunnie. Dlatego też, za Skibińskim, używam tu wyrażenia "zachowanie językowe”. Jest to bardzo szerokie, czynnościowe, procesualne $\mathrm{i}$ - by tak rzec - także sensualne rozumienie języka. Nie odnosi się ono bowiem ani do abstrakcyjnie pojętego systemu językowego, ani też do pragmatycznie zwartościowanych aktów mowy, lecz do całościowo pojętego zachowania człowieka. Zachowanie językowe to nie tylko produkowanie określonych dźwięków, które na mocy konwencji układają się w ciągi semantyczne. Obejmuje ono także wszelkie reakcje organizmu, emocje, odruchy cielesne, doznania zmysłowe, ruch ciała, a zatem wskazuje na całościowo rozumianą, praktyczną sferę ludzkiego życia i zachowania ${ }^{13}$. Raczej $\mathrm{w}$ jego obrębie, a nie poprzez tak rozumiane zachowanie językowe, człowiek jako podmiot kognicji poznaje świat. Zachowanie językowe nie zakłada referencji, a więc odniesienia słów do realności. To, do czego się odnosimy, to za każdym razem nasze własne doświadczenia, zapośredniczane i wyrażane poprzez język. Na ich podstawie konstruujemy świat. Język jawi się tu zatem jako wyjątkowo złożony akt, obejmujący człowieka w pełni jego uposażenia, sfunkcjonalizowany wobec organizowania i orientowania jego zachowań ${ }^{14}$.

Prezentując koncepcje konstruktywistów, używałam pojęć rzeczywistości i realności. Są one bardzo ważne i wymagają choćby skrótowego komentarza, by nie ulegać obiegowym i nadzwyczaj niepoprawnym uwagom oponentów tego nurtu, w myśl których konstruktywizm odrzuca rzeczywi-

\footnotetext{
12 E. von Glasersfeld, Distinguishing the Observer: An Attempt at Interpreting Maturana. Tekst dostępny na stronie http://vonglasersfeld.com/125.2 [dostęp 01.09.2017].

13 Przykładem praktycznego zastosowania tych tez jest artykuł S. Moser, "Walking and Falling". Language as Media Embodiment, "Constructivist Foundations” 2008, Vol. 3, No. 3, s. 260-268.

14 Więcej na temat koncepcji Maturany zob. H. R. Maturana, F. J. Varela, Autopoiesis and Cognition. The Realization of the Living, Dordrecht - Boston - London 1980; H. Maturana, Ontologia obserwacji. Biologiczne podstawy samoświadomości i fizykalna dziedzina egzystencji, w: Radykalny konstruktywizm, przeł. B. Ryż, w: Radykalny konstruktywizm, s. 77-129. Omówienie tej koncepcji i opis nowego projektu języka w: A. Skibiński, Homo Significus. Autorozprawa o poznaniu-języku, Warszawa 2003, s. 130-213.
} 
stość, rozumie ją jako wyłącznie językowy konstrukt lub w ogóle nie wypowiada się na jej temat. Sposób, w jaki konstruktywiści postrzegają świat, najlepiej oddaje krótkie zdanie wypowiedziane przez Glasersfelda: „Radyklany konstruktywizm nie odrzuca świata zewnętrznego, neguje jedynie możliwość jego poznania"15. Jeśli mielibyśmy ściśle posługiwać się proponowanym $w$ dyskursach radykalnie konstruktywistycznych instrumentarium pojęciowym, to musielibyśmy utrzymać dystynkcję realności i rzeczywistości (Realität i Wirklichkeit). Ta pierwsza odnosi się do tego, do czego nie mamy niezapośredniczonego dostępu, co znajduje się poza naszym poznawczym doświadczeniem, natomiast druga dotyczy tego, co funkcjonuje $\mathrm{w}$ opisie, stanowiąc $w$ ten sposób konceptualizację, konstrukcję czy też interpretację realności. Realność to zatem świat realny, obiektywny, istniejący, lecz niepoznawalny. W języku polskim wszystkie te słowa funkcjonują jako synonimy, dlatego tak trudno przetransponować dyskurs konstruktywistyczny z obszaru języka niemieckiego do polszczyzny. Mimo to, podejmując rozważania epistemologiczne, interesującą dystynkcję trzeba mieć na uwadze.

Kolejną istotną kwestią jest to, by, zaproponowawszy konstruktywistyczny kontekst, precyzyjnie postawić pytania odnośnie do czynności interpretacyjnych. Sądzę, że pytanie, czy Herbert był konstruktywistą, jest obarczone błędem, kieruje bowiem namysł na intelektualne uposażenie twórcy i jego zaplecze filozoficzne, które w żadnej mierze nie mogło być konstruktywistyczne, tak ze względu na wspólnotę interpretacyjną, w której ramach kształtował się jego światopogląd, jak i z uwagi na to, że w czasie, w którym powstawały jego utwory, konstruktywizm nie był szerzej znany lub po prostu pewne jego tezy nie zostały jeszcze w ogóle sformułowane. Wychowanek Henryka Elzenberga był obeznany przede wszystkim z Ingardenowską fenomenologią ${ }^{16}$, nieobcy był mu spór realizmu $\mathrm{z}$ idealizmem, bliska, choć niejednoznacznie w twórczości waloryzowana, była także Herbertowi filozofia Nietzschego ${ }^{17}$. Dyskurs autora Pana Cogito, zarówno w zakresie poetyckim, jak i eseistycznym, zachowywał charakter ontologizujący. Pytanie należy zatem sformułować inaczej - czy dzięki zastosowaniu do interpretacji wierszy Herberta pewnych tez konstruktywistycznych można uzyskać spójne

\footnotetext{
15 W oryginale: Radical constructivism does not deny a world beyond our experiential interface, but it denies the possibility of knowing it. Cyt. za: V. Kenny, Continous Dialogues. Ernst von Glaserseld's Answers to a Wide Variety of Questioners on the Oikos Web Site 1997-2010, "Constructivist Foundations" 2011, Vol. 6, No. 2, s. 206.

16 Zob. więcej na ten temat: J.M. Ruszar, Od wydawcy. Spór o istnienie świata, w: M. Śniedziewska, Wierność rzeczywistości, s. 125-128.

17 M. Mikołajczak, „Wierność ziemi”. Związki z Nietzschem, w: tejże, Pomiędzy końcem a apokalipsą. O wyobraźni poetyckiej Zbigniewa Herberta, Toruń 2013, s. 230-272.
} 
i sensowne wnioski? Sądzę, że jest to możliwe. Poniżej wskażę kilka tropów interpretacyjnych, które stwarzają taką możliwość.

\section{Konstruktywizujący trop pierwszy: zachowanie językowe jako wyraz całościowo pojętej aktywności podmiotu poznania w wierszach Herberta}

Podmiot wierszy Herberta, jeśli określić go dodatkowo jako podmiot poznający, jest zawsze aktywny, a poznawanie stanowi nie wyizolowaną czynność, lecz integralny element jego całościowego uposażenia. Poznawanie jest tu doświadczaniem rozumianym jako dotykanie, smakowanie, czucie świata, sensualne i emocjonalne reakcje na jego bogactwo. To obserwacja, ale uczestnicząca, doznająca, zawsze w obszarze tego, co poznawane, niejako poprzez zmniejszenie dystansu względem przedmiotu. Pan Cogito poznaje świat poprzez doświadczenie, jego poznawcza perspektywa nie jest zewnętrzna, lecz każdorazowo bierze się z doświadczenia egzystencjalnego. Poznanie to ma nie tylko stricte intelektualny charakter, jest bowiem także poznaniem poprzez intuicję i za pomocą intuicji, a także wyobraźni.

W wierszu Pan Cogito a myśl czysta ${ }^{18}$ najdobitniej wyrażone jest przekonanie, że wyizolowanie myśli, efektu naszej aktywności intelektualnej, jest po prostu niemożliwe. Nawet największe skupienie nie uczyni myśli czystą, zawsze bowiem będzie skażona tym, co przynosi porządek życia, i to życia w jego najbardziej prozaicznym wymiarze. Oto mamy „blaszane puszki, drewno i kępkę czyichś włosów", w sposób natrętny i nieunikniony objawiające się świadomości podmiotu, który chce się oddać czystemu, nieskażonemu myśleniu. Myśl zawsze będzie przepełniona tym, co doświadczone i doświadczane, tak w wymiarze wzrokowym, jak i słuchowym, a nawet zapachowym i dotykowym. Ciało będzie przypominało o doświadczonym i przeżytym doznaniu cykania świerszczy i zapachu morza, o tym także, a właściwie przede wszystkim, że było ono dotykane (,,czuł pod żebrem palce nieobecnej"). To właśnie zmysł dotyku wydaje się najistotniejszy w Herbertowskiej epistemologii. I tak w wierszu Dotyk ${ }^{19}$ zmysły objawiają "podwójną prawdę", oczy w swej „chwiejnej mądrości” przedstawiają nam niepewne kolory, a słuch jedynie zamęt. Dotyk natomiast jest pewny, znajduje się na "skraju prawdy", pozwala oddzielić pewność od pozoru, jakby

18 Cytaty z wierszy Herberta na podstawie wydania: Z. Herbert, Wiersze zebrane, oprac. edytorskie R. Krynicki, Kraków 2011. Wskazując wiersz, będę podawać tom, z którego oryginalnie pochodzi, skrót Wz i stronę. Z. Herbert, Pan Cogito a myśl czysta [Pan Cogito, Wz, s. 380].

19 Z. Herbert, Dotyk [Hermes, pies i gwiazda, Wz, s. 84-85]. 
był najbardziej bliskim, bo najbardziej sensualnym sposobem doświadczania rzeczywistości ${ }^{20}$.

Poznanie jest zatem zanurzone w doznawaniu i doświadczaniu świata, myśli są zawsze już skażone, już nieczyste, „umeblowane”, jak wyraża się poeta. Nie możemy tu zatem mówić po Husserlowsku o czystej świadomości i fenomenologicznej redukcji, w efekcie której doszłoby do prezentowania czystych przeżyće ${ }^{21}$. Czysta świadomość jest świadomością bezpodmiotową, bez empirycznego $j a$, a fenomenologiczna myśl jest myślą niczyją, gdy tymczasem aktualizujące się $\mathrm{w}$ twórczości Herberta ja jest zawsze realne, empiryczne, konkretne, dane w bogactwie swych intelektualno-psychiczno-sensualnych przeżyć. Satori - pojęcie zaczerpnięte przez Herberta z buddyzmu, ściślej z jednej z jego odmian - zen, oznacza tak pożądane $\mathrm{w}$ tej religii oświecenie, a zatem stan czystego, absolutnego zrozumienia, wewnętrznego przeświadczenia, dla którego osiągnięcia konieczne jest wszak długotrwałe i stopniowe oczyszczenie umysłu z pragnień, wyobrażeń, skojarzeń itd. Transponując to na język poetycki analizowanego wiersza, można powiedzieć, że satori wymaga, by oczyścić myśli z całego ich umeblowania. Pan Cogito osiągnie ten stan, będzie w końcu "pusty i zdumiewający”, ale wtedy dopiero, gdy "ostygnie". Słowo to potocznie oznacza śmierć, finalne wersy utworu wzmacniają zatem wyrażane w nim wcześniej przekonanie, że podmiot poznający nigdy nie jest w stanie choćby zbliżyć się do ideału poznania czystego, nieskażonego i niezakłóconego.

\section{Konstruktywizujący trop drugi: \\ Wobec rzeczywistości czy konstrukcji rzeczywistości? Niejednoznaczne Herbertowe ontologizowanie}

Jeśli przyjmiemy, że typ poznania presuponowany lub wprost określany w utworach Herberta ma charakter konstruktywistyczny, pozostaje jeszcze kwestia owego ontologizowania, o którym wspomniałam na po-

20 Dotyk pojawia się w wielu utworach Herberta, jest dla niego zawsze najważniejszym i najpewniejszym ze zmysłów, por. także wiersz Alienacje Pana Cogito [Pan Cogito, Wz, s. 388-389].

21 Por. np. E. Husserl, Idee czystej fenomenologii i fenomenologicznej filozofii, przeł. i przypisami opatrzyła D. Gierulanka, Warszawa 1967; tenże, Idea fenomenologii. Pięć wykładów, przeł. J. Sidorek, wstęp A. Półtawski, Warszawa 1990. U samego Husserla jest to problem bardziej skomplikowany; w tekście głównym znacznie upraszczam jego myśl, zwłaszcza że w kwestii czystej świadomości, czystego ja i ja empirycznego Husserl nie był jednoznaczny i zmieniał na ten temat poglądy, por.: J. Czarkowski, Koncepcja czystego Ja w fenomenologii transcendentalnej Edmunda Husserla, „Acta Universitatis Nicolai Copernici. Filozofia” 1995, nr 16, s. 19-35. 
czątku. Dyskurs konstruktywistyczny intencyjnie miał być uwolniony od pustych metafor metafizycznych, a tradycyjne pojęcia ontologii, jak „byt", „istota”, nawet "przedmiot” miały zostać usunięte jako zupełnie nieprzydatne podczas analizy procesu poznania. W nie-dualizującym sposobie mówienia Josefa Mitterera, o przedmiocie mówi się jako o deskrypcji so far, która jest zmieniana i kontynuowana w postaci deskrypcji from now on, poznanie jest ujmowane jako odbywające się od przedmiotu, a nie do przedmiotu, jak w jego tradycyjnym, realistycznym modelu ${ }^{22}$. Akty poznawcze kierują się zatem od przedmiotu, w nieustannym procesie zmiany, w którym dochodzi jedynie do tymczasowych ustabilizowań, owych momentalnych esencji. Tamta strona dyskursu, w obrębie której egzystował przedmiot jako dany poza, poza opisem, zostaje wyeliminowana do tego stopnia, że nie można już mówić o substancjalnym ujęciu obiektu. Siegfried Schmidt, podążając tropem nie-esencjalizującej myśli Mitterera, formułuje zatem pojęcie procesu zamiast przedmiotu ${ }^{23}$. Mając to wszystko na uwadze, jako uzupełnienie uwag o Herbertowskim aktywnym modelu poznania, konieczne wydaje się określenie, jak $\mathrm{w}$ jego wierszach ujmowana jest rzeczywistość/realność/przedmiot.

Zacznę od leksykalnego uposażenia utworów poety. Pojęcia "byt", "przedmiot”, "istota rzeczy” stanowią dość ważny korpus leksykalny utworów Herberta. "Substancja” pojawia się w wierszu Pan Cogito o potrzebie ścisłości, w Bajce o gwoździu mamy „rzecz" i przymiotnik „realne”, w wierszu Zwierciadło wędruje po gościńcu zaś „realność” ${ }^{24}$. Uważniej chciałabym się tu przyjrzeć Uprawie filozofii ${ }^{25}$, utworowi, w którym tradycyjne pojęcia dyskursu ontologizującego są jednak ujęte w sposób krytyczny. Oto filozof, funkcjonujący jako podmiot liryczny, wymyśla słowo „byt”. Jest ono „twarde i bezbarwne", bo niefunkcjonalne dla poznania i doświadczania rzeczywistości. Kamień filozoficzny jest martwy, żeby go odnaleźć trzeba by wyzbyć się „ciepłych liści”, a „zachód słońca”, który chłonie się pełnią swego psychiczno-intelektualno-sensualnego doświadczenia, nazwać „zjawiskiem”, użyć zatem

22 J. Mitterer, Tamta strona filozofii, Przeciwko dualistycznej zasadzie poznania, przeł. M. Łukasiewicz, Warszawa 1996, tenże, Ucieczka z dowolności, przeł. A. Zeidler-Janiszewska, Warszawa 2004. Więcej na temat epistemologii i retoryki nie-dualizującego sposobu mówienia M. Cyzman, Nieznośna płynność rzeczy.

23 S. Schmidt, From Objects to Processes. A Proposal to Rewrite Radical Constructivism, "Constructivist Foundations" 2011, Vol. 7, No. 1, s. 1-9.

24 Z. Herbert, Pan Cogito o potrzebie ścisłości [Raport z oblężonego miasta, Wz, s. 517-522]; Z. Herbert, Bajka o gwoździu [Elegia na odejście, Wz, s. 574]; Z. Herbert, Zwierciadło wędruje po gościńcu [Rovigo, Wz, s. 614].

25 Z. Herbert, Uprawa filozofii [Struna światła, Wz, s. 46]. 
ponownie pojęcia z dyskursu ontologizującego. Przestrzeń w jej bogactwie i różnorodności ma być doświadczana, a nie opisywana za pomocą martwych, pustych pojęć ${ }^{26}$. Filozof $\mathrm{z}$ wiersza Herberta jest groteskowy, wymyśla dumnie brzmiące pojęcia i konstruuje nowe byty, jak „u szczytu walca wahadło", a jednocześnie macha małymi rączkami. Drewniane stołki i inne przedmioty nie potrzebują idei, zwłaszcza tak abstrakcyjnych, jak idea nieskończoności, co Herbert wyraża w sposób ironiczny, a nawet zjadliwy względem filozofa. Oto idea nieskończoności rośnie tak, że za chwilę „przerośnie już jego głowę". Pojęcia i konstrukty filozoficzne wydają się nie tyle upośredniać poznanie, ile w ogóle je uniemożliwiać, są autoteliczne, zachodzą obok procesu doświadczania świata, a nie wraz z nim.

W wierszu Objawienie ${ }^{27}$ ponownie dochodzi do, jak pisze Stanisław Barańczak, „,ironicznej kompromitacji [...] ideału doskonałości” ${ }^{28}$. Oto doznanie, że dotyka się właśnie tu i teraz istoty rzeczy, zostaje trywialnie zaburzone przez dzwonek listonosza do drzwi, co więcej - musi ustąpić jeszcze bardziej trywialnym czynnościom, jak nastawienie herbaty i wylanie brudnej wody. Dotknięcie „istoty rzeczy” - kolejne typowe wyrażenie dyskursu ontologizującego - ma zrodzić wiedzę, poeta pisze "będę wiedział”, chodzi więc o poznanie pełne, pewne, ostateczne. Pobrzmiewa tu ta sama sceptyczna refleksja, którą wobec myśli czystej i "nieumeblowanej” wyrażał Herbert w wierszu Pan Cogito a myśl czysta. Idea szklanki rozbija się o... szklankę, „rozlewa na stole", w pokoju bynajmniej niedoskonałym. Poznanie wydaje się zatem zawsze $\mathrm{w}$ osobliwy sposób skażone, zanurzone $\mathrm{w}$ porządku życia, a istota rzeczy jest albo kolejnym martwym pojęciem metafizycznym, albo też czymś realnym, lecz niepodlegającym racjonalnemu poznaniu i komunikacji.

Uprawa filozofii to wiersz, który doskonale obrazuje stałą tendencję w twórczości poety, ów poetycki dyskurs krytyczny względem filozofii i filozofów. W utworze Ala ma kota. W obronie analfabetyzmu owa niechęć zyskuje nadzwyczaj bezpośredni i dosadny wyraz: „wszelka filozofia / jest zbyteczna / a nawet szkodliwa" ${ }^{29}$. Ten antyfilozoficzny dyskurs poetycki może stanowić doskonałą ilustrację tez konstruktywistów, a wręcz poetycki komentarz do filozoficznego dyskursu metakrytycznego, jaki uprawia Jo-

\footnotetext{
${ }^{26}$ J. Bielska-Krawczyk, analizując ten wiersz, także wskazuje na prymat zmysłowego poznania rzeczywistości, chęć zanurzenia się w niej, a nie w martwych pojęciach filozoficznych, por. J. Bielska-Krawczyk, "Nowe trwanie poza śmierć". Herbert - sztuka a metafizyka, w: Między nami a światem. Bóg $i$ świat w twórczości Zbigniewa Herberta, s. 95-110.

27 Z. Herbert, Objawienie [Studium przedmiotu, Wz, s. 291-292].

28 S. Barańczak, Uciekinier z Utopii. O poezji Zbigniewa Herberta, Wrocław 1994, s. 108-109.

29 Z. Herbert, Ala ma kota. W obronie analfabetyzmu [Rovigo, Wz, s. 684].
} 
sef Mitterer w Tamtej stronie filozofii ${ }^{30}$. Owa krytyka doskonale harmonizuje u Herberta z modelem poznania, o którym pisałam wcześniej. Warto jednak $\mathrm{w}$ tym momencie podkreślić, że poeta bynajmniej nie sprowadzał poznania do jego wyłącznie racjonalnego i sensualnego wymiaru, jak można by przypuszczać na podstawie interpretacji kilku wybranych wierszy. Choćby lektura Labiryntu nad morzem dowodzi bowiem, że Herbertowi nie były obce momenty szczególnych olśnień, rozbłysków świadomości, niezwykłego intuicyjnego wglądu w rzeczywistość, zwłaszcza wówczas, gdy obcował ze sztuką. Te epifanie, chwilowe rozbłyski, gdy oto nagle po prostu się wie, uwikłane jednak zawsze w porządek życia, wcale nie przeczą tezie o konstruktywistycznym modelu poznania, jaki jest presuponowany w twórczości Herberta. Glasersfeld także wspominał o takim typie szczególnego poznania, które dane jest mistykom lub artystom, jakby przebicia się przez świat skonstruowany. Nie podejmował nad nim rozważań, bo tego typu doświadczenie nie może być ani badane, ani komunikowane w sposób racjonalny, jako takie więc nie mieściło się w obszarze dociekań konstruktywistycznych. Sądzę, że i taka refleksja pobrzmiewa u Herberta. Olśnienia się przydarzają, zwłaszcza podczas kontaktu ze sztuką, jednak są tak ulotne, że nie mogą być ani powtórzone, ani stać się przedmiotem opisu. Zachwyt, który rodzi potrzebę opisu tak dokładnego, by objawiła się w nim z całą dokładnością jakaś ulotna samoobecność przedmiotu, dana w chwili epifanii, poddany racjonalnej pracy umysłu ustępuje miejsca rozczarowaniu. Nie da się bowiem ani zapamiętać, ani tym bardziej opisać „obrazu dokładniejszego od wszystkich reprodukcji" ${ }^{31}$.

Herbert zatem nie tyle zbliża się do rzeczywistości, nie tyle jest jej wierny, ile raczej ustawicznie się z nią zmaga i stawia pytania o możliwość jej poznania, o zakres i sposób jej skonstruowania i relacje zachodzące względem opisu.

Sprawdzanie możliwości zastosowania konstruktywistycznego kontekstu do interpretacji twórczości Herberta oznacza konieczność postawienia pytania o relację między językiem a rzeczywistością, o to, czy przedmiot jawi się w niej jako dany poza opisem, czy też jest zlokalizowany na tej samej płaszczyźnie, co opis. Jest to jedna z najtrudniejszych kwestii epistemologicznych, również dla samych konstruktywistów.

30 J. Mitterer, Tamta strona filozofii. Oczywiście owa sformułowana krytyka filozofii jest dość dwuznaczna, tak w obrębie samej filozofii, jak i poezji, zważywszy na to, że w obu tych obszarach podejmuje się jednocześnie wątki filozoficzne i poddaje je namysłowi.

31 Z. Herbert, Labirynt nad morzem, "Zeszyty Literackie", Warszawa 2000, s. 17-18. 
Zacznę od kilku uwag na temat utworu, którego tradycyjne interpretacje przeprowadzane $\mathrm{w}$ duchu realistycznym mogłyby $\mathrm{w}$ zasadzie już na wstępie uczynić dalsze konstruktywistyczne dywagacje o poezji Herberta pozbawionymi sensu. Oto w wierszu Stołek przedmioty mówią ,jesteśmy prawdziwi, a wierność rzeczy otwiera nam oczy". Utwór ten stanowi ekspozycję wyjątkowo czułego opisu tytułowego przedmiotu, który w porządku wewnątrztekstowym jest także adresatem lirycznego monologu. Zwolennicy realistycznych odczytań poezji Herberta znajdą tu wyrażone expresiss verbis przekonanie o dostępnej naszemu poznaniu rzeczywistości, której należy oddać sprawiedliwość, opisywać ją w sposób adekwatny, wbrew myślowym uzurpacjom, które ignorują świadectwo zmysłów, doświadczanie świata, a w miejsce przedmiotu podstawiają pustkę. Można by wysunąć tezę, że w Stołku mamy obronę realności i poznawalności rzeczywistości. W tym kontekście pewnie wielu interpretatorów pokusiłoby się o stwierdzenie, że jest to wiersz przeciwko konstruktywistom i ich sposobom myślenia. Aby jednak zaproponować sensowny kontrargument dla tradycyjnych odczytań tego typu, konieczne wydaje się rozważenie problematycznej kwestii relacji przedmiot (rzeczywistość) - opis (język) od strony epistemologicznej i semantycznej.

Celowo za przedmiot refleksji wybieram koncepcję, która jest oczyszczona $\mathrm{z}$ esencjalizmu, koncepcję, w której brak założenia rzeczywistości istniejącej poza dyskursem. W nie-dualizującym sposobie mówienia na "tamtą stronę dyskursu" nie można się powoływać, bowiem logika myślenia nie-esencjalizującego nakazuje prowadzić poznanie o d przedmiotu $\mathrm{w}$ stronę zmiany, a nie d o przedmiotu w stronę prawdy. Przedmiot jako opis so far dzieje się $\mathrm{w}$ dyskursie, podlega ustawicznej zmienności i jako proces może stabilizować się jedynie chwilowo. Dlatego też w sytuacji starcia się dwu kontrowersyjnych opisów, prowadzonych od przedmiotu, nie jest możliwe cofnięcie się do przedmiotu w celu rozstrzygnięcia ich poprawności czy adekwatności. Cofnięcie takie dokonuje się w dyskursach dualizujących i esencjalizujących, każdorazowo przy założeniu, że obiekt funkcjonuje poza dyskursem. Ocena poprawności opisu dokonuje się tu w sposób arbitralny, nie jest bowiem możliwe nieopisowe ujęcie przedmiotu, co swoją drogą obnaża nieracjonalność i opresywność dyskursu dualizującego. Przedmiot jest zawsze "tępy i niemy" 32, na płaszczyźnie dyskursu może więc funkcjonować

32 Tego sformułowania używa J. Mitterer, dumb and silent $\mathrm{w}$ oryginale angielskim, por. J. Mitterer, On Interpretation, "Constructivist Foundations" 2013, Vol. 8, No. 2, s. 143-147. Na temat Mittererowskiej i konstruktywistycznej koncepcji interpretacji zob. także: M. Cyzman, Po "tamtej stronie" interpretacji. Koncepcja interpretacji Ernsta von Glasersfelda i Josefa Mitterera, „Litteraria 
jedynie dzięki tym, którzy w jego imieniu przemówią, a przemówią przecież zawsze w sposób uwarunkowany kulturowo i społecznie, jako przedstawiciele określonych wspólnot interpretacyjnych. Nie jest możliwe sformułowanie żadnych interpretacyjnie transcendentnych uwag o przedmiocie. Oponenci tego sposobu ujmowania rzeczywistości usiłują obalić epistemologiczno-semantyczny model Mitterera za pomocą ironicznego wskazania, że przecież nikt z nas nie je opisów jabłek, lecz jabłka po prostu, co ma stanowić argument na rzecz istnienia rzeczywistości jako takiej, dostępnej poza językiem i możliwej do uchwycenia. Empiria ma zatem przeczyć ustaleniom nie-dualistów. Nawet badacze dość przychylnie nastawieni do konstruktywi$\mathrm{zmu}$, nierzadko też $\mathrm{w}$ jakiś sposób się z nim identyfikujący, podkreślają, że założenie obiektu nie-językowego, materialnego, jest konieczne, by wykonać pierwszą deskrypcję ${ }^{33}$.

Jak wskazują dociekania austriackiej filozofki Kathariny Neges ${ }^{34}$, problem nie tkwi bynajmniej w tym, czy jemy jabłka, czy opisy jabłek, dylemat ten nie powstaje bowiem $\mathrm{w}$ ramach nie-dualizującej epistemologii Mitterera, Schmidta i innych konstruktywistów spod znaku nie-dualizmu. Zdanie ,jem opis jabłka" i ,jem rzecz różną od języka" jest absurdalne tak dla realistów, jak i dla konstruktywistów, z tym, że w ramach nie-ontologizującego dyskursu konstruktywistycznego nie można w ogóle sformułować takich zdań. Obie kategorie, jabłko, reprezentujące rzeczywistość, i opis jabłka, reprezentujący język, są w nie-dualizmie nierozłączne, funkcjonują na jednej płaszczyźnie, nie można zatem z perspektywy jednej z nich pytać o drugą. Pytanie o różnicę między jabłkiem i opisem jabłka stanowi wytwór dyskursu dualizującego, w którym rolę dominującą odgrywa jeszcze słownik ontologiczny, nie może więc zostać postawione $\mathrm{w}$ ramach nie-dualizmu, który tę różnicę po prostu znosi.

Wybór nie-dualizującej filozofii Mitterera jako przykład tego, w jaki sposób konstruktywizm widzi, a raczej znosi, relację opisu i przedmiotu, wydaje się o tyle funkcjonalny dla prowadzonych tu rozważań, że uchyla kontro-

Copernicana" 2016, nr 3, s. 73-86, taż, Jak radyklana może być radykalna koncepcja interpretacji? O nie-dualizujacym modelu interpretacji Josefa Mitterera, "Przegląd Kulturoznawczy” 2015, nr 1, s. $1-14$.

33 Zob. np. V. Gadenne, The Construction of Realism, "Constructivist Foundations" 2008, Vol. 3, No. 3, s. 153-159; P. Strasser, In, the Nameless God of Dualism. Some Remarks on St. John, the First Non-dualist, and His Renowed Follower, Josef Mitterer, tamże, s. 269-272.

34 K. Neges, Non-dualism and World: Ontological Questions in the Non-dualizing Mode of Discourse, "Constructivist Foundations" 2013, Vol. 8, No. 2, s. 158-165. Pojawia się tu oczywiście sporo interesujących argumentów na rzecz nie-dualizmu, nie mogę ich jednak przytoczyć w tekście głównym, wybierając tylko to, co wydaje się dla realizowanego tematu najważniejsze. 
wersje wobec sposobu, w jaki kwestia ta jest ujęta w innych pismach konstruktywistycznych. Oto bowiem dokładna analiza tekstów radykalnie konstruktywistycznych, np. Glasersfelda, czy tekstów pragmatystycznych, np. Richarda Rorty'ego, wskazuje, że wszędzie tu jednak można zidentyfikować słabsze lub mocniejsze, założenie substratum, a więc owej rzeczywistości danej poza dyskursem ${ }^{35}$. Konstruktywistyczny słownik nie zawsze jest ścisły, a nie-esencjalizująca logika nie zawsze konsekwentnie stosowana.

Wracam zatem do pytania, jak funkcjonuje owa "tamta strona dyskursu" w poetyckim świecie Herberta? Jak jest ujmowana rzeczywistość? Czy jest dana jako pozostająca poza językiem i poznawalna, czy też jej założenie jest zbyt słabe, by sensownie rozprawiać o konstruktywistycznej wymowie wierszy Herberta?

Przedmiot i opis przedmiotu to niewątpliwie jeden $\mathrm{z}$ istotniejszych wątków twórczości Herberta w ogóle, nie tylko tej stricte poetyckiej, eseje o sztuce to przecież nic innego jak serie opisów szczególnego typu obiektów, jakimi są dzieła sztuki. W wierszach dominują jednak przedmioty pospolite, stołki czy krzesła, a także przedmioty w sensie ogólnym, jako odnośniki do pewnej klasy obiektów materialnych.

W poetyckiej miniaturze o znamiennym tytule Żeby wywieść przedmioty ${ }^{36}$ przebywają one w królestwie milczenia, co można potraktować jako literacki odpowiednik Mittererowskiego sformułowania o przedmiotach „tępych i niemych". Są one wprawdzie wywodliwe z owego królestwa milczenia, ale jedynie w drodze gwałtu, przemocy. Przedmioty wyrwane $z$ tego królestwa objawiają się dalej na płaszczyźnie języka, o czym może świadczyć pojawiająca się tu figura "zdyszanego epika". Dom "gada" jego językiem, "gada" to, o czym łóżko i zasłony dotychczas milczały. Przedmiot przemawia więc głosem swego przedstawiciela, który odtąd będzie go reprezentował i w jego imieniu zaistnieje na płaszczyźnie dyskursu. Ten bardzo Latourowski w swej wymowie utwór nie poddaje się jednak jednoznacznej interpretacji epistemologicznej, można go bowiem przeczytać zarówno w kontekście paradygmatu realistycznego, jak i konstruktywistycznego. Podobne zmagania poznawcze obserwujemy w wierszu Głos ${ }^{37}$. Próba usłyszenia głosu świata, morza, pola, lasu i ziemi kończy się niepowodzeniem. To, co rejestruje podmiot, to doznania zmysłowe: szumu, uderzeń fali, żółtych i zielonych barw. Albo więc świat

\footnotetext{
35 Nie sposób przeprowadzić tu szerszej dyskusji, najtrafniej rzecz ujął sam Mitterer, por. J. Mitterer, Ucieczka z dowolności, s. 15. Więcej na ten temat w książce M. Cyzman, Nieznośna płynność rzeczy.

36 Z. Herbert, Żeby wywieść przedmioty [Pan Cogito, Wz, s. 396].

37 Z. Herbert, Głos [Hermes, pies i gwiazda, Wz, s. 88-89].
} 
jest niemy, albo też doznający go podmiot jest głuchy i nie jest w stanie usłyszeć i wypowiedzieć tego, czym i jak świat przemawia. Może jednak jest i tak, że owo milczenie, ów brak głosu, właściwy jest zarówno światu, jak i poznającemu podmiotowi, dlatego też zamiast próbować usłyszeć, czym świat przemawia, należałoby raczej poprzestać na jego doświadczaniu, na próbie osiągnięcia z nim harmonii, „wziąć się pod rękę” i wspólnie z nim po prostu „iść przed siebie”? I zamiast poszukiwać adekwatnych opisów, niemożliwych do sformułowania, po prostu jedynie (a może aż?) „czule przemawiać do rzeczy" (wiersz Nigdy o tobie $^{38}$ )?

Można by założyć, że Żeby wywieść przedmioty i Głos sugerują niemożność sensownego założenia "tamtej strony" (lub przynajmniej wahanie co do takiej możliwości), to, co chcielibyśmy w niej ulokować, zawsze będzie bowiem dane przez opis, choćby rudymentarny. Przedmioty nie mają własnego głosu, istoty, która czeka na odkrycie, nie są w stanie przemawiać we własnym imieniu. Byłoby to wskazanie na konstruktywistyczne ujęcie relacji opis - przedmiot i jednak nie-esencjalistyczne rozumienie tego ostatniego ${ }^{39}$. Można by pójść tym tropem dalej i na liczne Herbertowe zmagania $\mathrm{z}$ opisem spojrzeć inaczej niż w dotychczas formułowanych interpretacjach. Nie byłyby to już próby, jakże przecież typowe, a nawet banalne, znalezienia odpowiedniego słowa dla rzeczy czy też usiłowania zbliżenia się do prawdy rzeczywistości. Można by potraktować te opisy jako zapis doświadczania przedmiotów przez poetę, zapis, który nawet jeśli powstaje w wyniku epifanii, nigdy nie będzie pełny, dookreślony i wierny; wierny jednak nie tyle rzeczywistości zewnętrznej, ile raczej osobliwemu nierzadko przeżyciu, jakie staje się udziałem podmiotu poznającego. Przedmiot, który dany jest w poetyckim sprawozdaniu Herberta, choć doświadczany indywidualnie, objawia się zawsze już w jego kulturowo-semantycznym uposażeniu zastanym przez podmiot. Od konotacji, w które obrasta, nie ma bowiem ucieczki, nie sformułujemy opisu, który nie byłby zanieczyszczony („umeblowany”) przez to, jak funkcjonował w serii już wykonanych i niekoniecznie poetyckich opisów. Dlatego tak kusząca wydaje się perspektywa opisu przedmiotu, którego nie ma. Herbert poświęcił mu nawet obszerne poetyckie Studium przedmiotu ${ }^{40}$, w którym wylicza rozliczne zalety nieistniejącego przedmiotu.

Przedmiot, którego nie ma, wydaje się otwarty na dowolne wypełnienie semantyczne. Nie ma ustabilizowanej funkcji (np. „nie służy do noszenia wody"), nie ma też żadnej historii i nie jest zanurzony w kulturze, przez

\footnotetext{
38 Z. Herbert, Nigdy o tobie [Hermes, pies i gwiazda, Wz, s. 109].

39 Podobnie można ująć miniaturę Drewniana kostka [Studium przedmiotu, Wz, s. 298].

40 Z. Herbert, Studium przedmiotu [Hermes, pies i gwiazda, Wz, s. 281-285].
} 
co wydaje się wolny od wszelkich konotacji i asocjacji („,nie tuliła go Antygona"). Przedmiot taki nie będzie też podlegał żadnej ewolucji, nie zmieni się („,śmierć/nie wydrze przedmiotu/którego nie ma"). Strefę tego, co nieistniejące, można ponadto dowolnie poszerzać, stworzyć pustą przestrzeń, która jest „piękniejsza od przedmiotu”, a i dalej wywodzić z tej domeny nieistnienia dowolne obiekty i dowolnie je modelować (,wyjmij / z cienia przedmiotu / [...] / krzesło"). Co ciekawe jednak, tak wykreowane, stwarzane wraz z opisem krzesło, choć nieistniejące, podlega dokładnie tym samym mechanizmom dyskursywnym, co przedmioty będące obiektem doświadczenia. Wolny od kulturowych konotacji raz dany na płaszczyźnie dyskursu natychmiast obrasta w serię opisów wskazujących na jego potencjalne funkcje i sensy, a te płyną już z kultury i noszą znamiona innych, faktycznie istniejących już opisów.

Na koniec tej części rozważań wrócę do wiersza Stołek. Jeśli spojrzeć na niego przez pryzmat konstruktywizmu, można w pojawiających się tu sformułowaniach widzieć nie tyle obronę rzeczywistości jako takiej, funkcjonującej po „tamtej stronie dyskursu”, lecz raczej wierność jej wszechstronnemu sensualno-intelektualnemu doświadczaniu. Doświadczamy rzeczy zawsze w sposób prawdziwy, a w realność doświadczanych przedmiotów nie możemy nie wierzyć, jeśli nasze poznanie ma być użyteczne i funkcjonalne, tzn. gwarantować nam udane, zgodne zagospodarowywanie się w świecie ${ }^{41}$.

Przedstawione powyżej sugestie dotyczące możliwości konstruktywistycznego ujęcia wierszy Herberta dają się traktować i konstruktywistycznie, i konstruktywnie. Stosując nie-esencjalizujące rozumowanie konstruktywistów, można powiedzieć, że skoro tekst jest „tępy i niemy”, da się go więc po Rortiańsku używać do dowolnych celów, to niewątpliwie kontekst konstruktywistyczny jest tak samo dobry, jak każdy inny. Oczywiście o ile $\mathrm{w}$ jego efekcie powstaną wewnętrznie niesprzeczne interpretacje i o ile zostaną one zaakceptowane $\mathrm{w}$ ramach jakiejś wspólnoty interpretacyjnej. Czy jednak w ramach rodzimej wspólnoty badaczy literatury powyższe uwagi okażą się konstruktywne? Nie wiadomo, gdyż opór ustabilizowanych interpretacji $\mathrm{w}$ duchu realistycznym wydaje się bardzo duży, a i konstruktywistycznych sugestii interpretacyjnych jest jeszcze zdecydowanie za mało, by mogły stanowić właściwy materiał empiryczny do dyskusji. Sądzę, że inne spojrzenie na twórczość Herberta może jednak nieco odświeżyć interpreta-

41 Zdaję sobie sprawę z tego, że dokonana tu aspektowa, skrótowa interpretacja wiesza Stołek jest jeszcze niewystarczająca i wymagałaby wzbogacenia o inne wątki. Kwestię pełniejszej interpretacji pozostawiam jednak na razie otwartą, trudno bowiem $\mathrm{w}$ tak krótkim szkicu dokonać pełniejszej analizy. 
cyjne status quo, wywołać interpretacyjną dynamikę. Nie chodzi przecież, raz jeszcze to podkreślę, ani o obalanie dotychczasowych opracowań wierszy polskiego poety, ani też o rozstrzygnięcie, czy jest to twórczość konstruktywistyczna czy realistyczna. Nawiązując do formuły Mitterera, można bowiem zapytać, jaką to czyni różnicę, czy jest konstruktywistyczna, czy realistyczna? Dramat poznania człowieka i jego zagospodarowywania się w rzeczywistości można wszak wyrażać na wiele różnych sposobów, a Herbert zdaje się to robić w sposób wyjątkowo poruszający. I bynajmniej nie tak jednoznaczny, jak mogłyby sugerować dominujące realistyczne odczytania jego poezji.

\section{Bibliografia}

Balicki Bogdan (2008), Nauka (o literaturze) z punktu widzenia radykalnego konstruktywizmu, w: Wzorce postrzegania rzeczywistości w nauce i społeczeństwie, red. B. Płonka-Syroka, Warszawa: Wydawnictwo DiG.

Barańczak Stanisław (1994), Uciekinier z Utopii. O poezji Zbigniewa Herberta, Wrocław: Wydawnictwo Naukowe PWN.

Bielska-Krawczyk Joanna (2012), „Nowe trwanie poza śmierć". Herbert - sztuka a metafizyka, w: Między nami a światem. Bóg i świat w twórczości Zbigniewa Herberta, red. J.M. Ruszar, R. Sioma, G. Halkiewicz-Sojak, Torun - Kraków: Wydawnictwo JMR Trans-Atlantyk, s. 95-110.

Bińczyk Ewa (2010), (Post)konstruktywizm na temat technonauki, „Zagadnienia Naukoznawstwa", nr 2, s. 231-251.

Cyzman Marzenna (2015), Jak radyklana może być radykalna koncepcja interpretacji? O nie-dualizujacym modelu interpretacji Josefa Mitterera, „Przegląd Kulturoznawczy", nr 1, s. 1-14.

Cyzman Marzenna (2015), Nieznośna płynność rzeczy. Dyskurs, retoryka, interpretacja w nie-dualizującym sposobie mówienia, Toruń: Wydawnictwo Naukowe Uniwersytetu Mikołaja Kopernika.

Cyzman Marzenna (2016), Po "tamtej stronie” interpretacji. Koncepcja interpretacji Ernsta von Glasersfelda i Josefa Mitterera, „Litteraria Copernicana”, nr 3, s. 73-86.

Cyzman Marzenna, Bohuszewicz Paweł (2016), Wokół pojęcia konstruktywizmu, „Litteraria Copernicana", nr 3, s. 7-14.

Czarkowski Józef (1995), Koncepcja czystego Ja w fenomenologii transcendentalnej Edmunda Husserla, „Acta Universitatis Nicolai Copernici. Filozofia”, nr 16, s. 19-35.

Fish Stanley (2008), Interpretacja, retoryka, polityka, red. A. Szahaj, przeł. K. Arbiszewski i in., Kraków: Univesitas.

Gadenne Volker (2008), The Construction of Realism, "Constructivist Foundations", Vol. 3, No. 3, special issue: The Non-dualizing Philosophy of Josef Mitterer, s. $153-159$. 
Glasersfeld Ernst (1984), An introduction to radical constructivism, w: The Invented Reality: How Do We Know What We Believe We Know? (Contributions to Constructivism), ed. P. Watzlawick, New York: W.W. Norton \& Company, s. 17-40.

Glasersfeld Ernst (1990), Distinguishing the Observer: An Attempt at Interpreting Maturana, http://vonglasersfeld.com/125.2.

Herbert Zbigniew (2000), Labirynt nad morzem, Warszawa: Zeszyty Literackie.

Herbert Zbigniew (2011), Wiersze zebrane, oprac. edytorskie R. Krynicki, Kraków: Wydawnictwo a5.

Husserl Edmund (1967), Idee czystej fenomenologii i fenomenologicznej filozofii, przeł. i przypisami opatrzyła D. Gierulanka, Warszawa: Państwowe Wydawnictwo Naukowe.

Husserl Edmund (1990), Idea fenomenologii. Pięć wykładów, przeł. J. Sidorek, wstęp A. Półtawski, Warszawa: Państwowe Wydawnictwo Naukowe.

Kenny Vincent (2011), Continous Dialogues. Ernst von Glaserseld's Answers to a Wide Variety of Questioners on the Oikos Web Site 1997-2010, "Constructivist Foundations", Vol. 6, No. 2, special issue: Commemorative Issue for Ernst von Glasersfeld, s. 204-212.

Kuźma Erazm (2006), Konstruktywizm, w: Konstruktywizm w badaniach literackich, red. E. Kuźma, J. Madejski, A. Skrendo, Kraków: Universitas, s. 1-12.

Maturana Humberto (2010), Ontologia obserwacji. Biologiczne podstawy samoświadomości i fizykalna dziedzina egzystencji, przeł. B. Ryż, w: Radykalny konstruktywizm, Antologia, red. B. Balicki, D. Lewiński, B. Ryż, E. Szczerbuk, Wrocław: Gajt, s. 77-129.

Maturana Humberto R., Varela Francisco J. (1980), Autopoiesis and Cognition. The Realization of the Living, Dordrecht - Boston - London: D. Reidel Publihing Company.

Między nami a światem. Bóg i świat w twórczości Zbigniewa Herberta (2012), red. Ruszar Józef M., Sioma Radosław, Halkiewicz-Sojak Grażyna, Torun - Kraków: Wydawnictwo JMR Trans-Atlantyk.

Mikołajczak Małgorzata (2013), „Wierność ziemi”. Związki z Nietzschem, w: tejże, Pomiędzy końcem a apokalipsą. O wyobraźni poetyckiej Zbigniewa Herberta, Torun: Wydawnictwo Naukowe Uniwersytetu Mikołaja Kopernika, s. 230-272.

Mitterer Josef (1996), Tamta strona filozofii. Przeciwko dualistycznej zasadzie poznania, przeł. M. Łukasiewicz, Warszawa: Oficyna Naukowa.

Mitterer Josef (2004), Ucieczka z dowolności, przeł. A. Zeidler-Janiszewska, Warszawa: Oficyna Naukowa.

Mitterer Josef (2008), (Radical) Constructivism - What Difference Does It Make?, "Constructivist Foundations", Vol. 3, No. 3, special issue: The Non-dualizing Philosophy of Josef Mitterer, s. 160-162.

Mitterer Josef (2013), On Interpretation, "Constructivist Foundations”, Vol. 8, No. 2, special issue: Non dualism. A Conceptual Revision?, s. 143-147.

Moser Sybille (2008), "Walking and Falling”. Language as Media Embodiment, "Constructivist Foundations", Vol. 3, No. 3, special issue: The Non-dualizing Philosophy of Josef Mitterer, s. 260-268.

Müller Karl H. (2008), Non-dualistic? Radical Constructivist?, „Constructivist Foundations", Vol. 3, No. 3, special issue: The Non-dualizing Philosophy of Josef Mitterer, s. $181-191$. 
Neges Katharina (2013), Non-dualism and World. Ontological Questions in the Non-dualizng Mode of Discourse, "Constructivist Foundations", Vol. 8, No. 2, special issue: Non dualism. A Conceptual Revision?, s. 158-165.

Piotrowska Ewa (2008), Społeczny konstruktywizm a matematyka, Poznań: Wydawnictwo Naukowe UAM.

Ruszar Józef M. (2013), Od wydawcy. Spór o istnienie świata, w: M. Śniedziewska, Wierność rzeczywistości. Zbigniew Herbert o postawie wobec świata i problemach jego reprezentacji, Kraków: Wydawnictwo JMR Trans-Atlantyk, s. 125-128.

Schmidt Siegfried (2010), Rzeczywistość obserwatora, w: Radykalny konstruktywizm. Antologia, red. B. Balicki, D. Lewiński, B. Ryż, E. Szczerbuk, Wrocław: Gajt, s. $243-260$.

Schmidt Siegfried (2011), From Objects to Processes. A Proposal to Rewrite Radical Constructivism, "Constructivism Foundations", Vol. 7, No. 1, Target Article by Sigfried J. Schmidt, From Objects to Processes. A Proposal to Rewrite Radical Constructivism, s. 1-9.

Skibiński Adam (2003), Homo Significus. Autorozprawa o poznaniu-języku, Warszawa: Imex - Graf.

Strasser Peter (2008), In, the Nameless God of Dualism. Some Remarks on St. John, the First Non-dualist, and His Renowed Follower, Josef Mitterer, "Constructivist Foundations", Vol. 3, No. 3, special issue: The Non-dualizing Philosophy of Josef Mitterer, s. 269-272.

Śniedziewska Magdalena (2013), Wierność rzeczywistości. Zbigniew Herbert o postawie wobec świata i problemach jego reprezentacji, Kraków: Wydawnictwo JMR Trans-Atlantyk.

Wendland Michał, Wiele twarzy konstruktywizmu. Różnorodność stanowisk konstruktywistycznych i ich klasyfikacje, „Kultura i Historia”, www.kulturaihistoria.umcs.lub lin.pl/archives/5004.

\section{Think, therefore I Feel, I Touch, I Taste... Some Epistemological Remarks on the Thinking of Mister Cogito}

\section{Summary}

The aim of the article is the attempt to read anewZbigniew Herbert's poems. The commonly accepted interpretations in Polish literary discourse place them in the context of realistic paradigm. Meanwhile the model of cognition in the poet's works is not so clear. It is possible to understand it in the constructivist way, taking into consideration Herberts own view that cognition has always active, dynamic, sensual and linguistic character. Ttherefore, it may be perceived as the correlate of languaging/linguistic behaviour of H. Maturana and E. von Glasersfeld.

Keywords: Polish poetry, cognition, constructivism, description, epistemology 